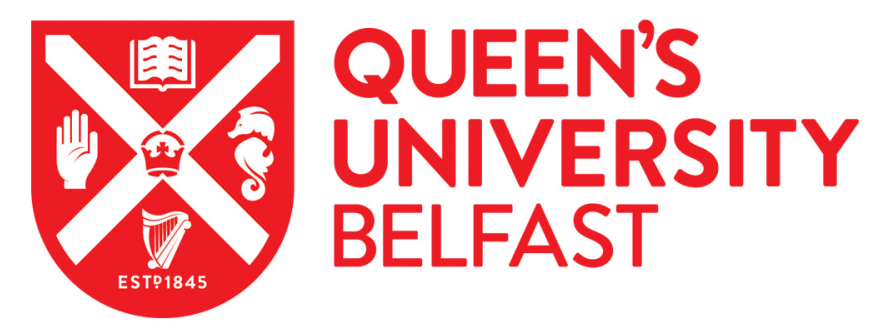

\title{
Marcuse and "the Christian Bourgeois Concept of Freedom"
}

Geoghegan, V. (2013). Marcuse and "the Christian Bourgeois Concept of Freedom". Telos, (165), 49-67. https://doi.org/10.3817/1213165049

\section{Published in:}

Telos

Document Version:

Early version, also known as pre-print

Queen's University Belfast - Research Portal:

Link to publication record in Queen's University Belfast Research Portal

Publisher rights

Copyright 2013 The author

\section{General rights}

Copyright for the publications made accessible via the Queen's University Belfast Research Portal is retained by the author(s) and / or other copyright owners and it is a condition of accessing these publications that users recognise and abide by the legal requirements associated with these rights.

Take down policy

The Research Portal is Queen's institutional repository that provides access to Queen's research output. Every effort has been made to ensure that content in the Research Portal does not infringe any person's rights, or applicable UK laws. If you discover content in the Research Portal that you believe breaches copyright or violates any law, please contact openaccess@qub.ac.uk. 


\section{Marcuse and "the Christian Bourgeois Concept of Freedom"}

\section{Vincent Geoghegan}

Contemporary theorization of the post-secular involves, and further invites, philosophical and historical reflection on the nature of the secular. Charles Taylor, in A Secular Age, has warned against what he terms "subtraction stories" of the emergence of modern secularism, narratives built around simplistic images of the rejection of, and liberation from, a Christian age of faith; these polemical confections need to be replaced, he argues, by accounts that register the complex processes by which secularism emerged out of the Christian, and how it bears the deep traces of that origin. ${ }^{1}$ Over seventy years before Taylor's injunction, Marcuse can be seen to be acting within its spirit when he explored what he termed "the Christian bourgeois concept of freedom," ${ }^{2}$ the formulation of which, in the tumultuous events of the Reformation, marks, he maintained, the beginnings of modern liberal secular society. In the subsequent forty years, as he refined and revised his anatomy of liberal capitalism, he produced significant, and at times highly provocative, analyses of liberal democracy in which one can glimpse his awareness of the ambiguous legacy of religion — on the one hand reinforcing its initial pivotal role, but on the other providing a source of contestation against the negative features of that structuring. Throughout, his perception of the nature of this negativity is deeply colored by his experience of fascism in the 1930s; time and again he returns to the trauma of Weimar Germany, where, he maintains, liberal capitalism gave

1. Charles Taylor, A Secular Age (Cambridge, MA: Belknap, Harvard UP, 2007), pp. 22-28.

2. Herbert Marcuse, "A Study on Authority," in Studies in Critical Philosophy, trans. Joris de Bres (London: New Left Books, 1972), p. 129. 
birth to fascism, and might readily do so again; this significantly marks his understanding of liberalism.

\section{The Reformation and the Ambiguities of Freedom}

In the mid-1930s, when Marcuse was seeking to notate the intricate dance of freedom and authority in modern capitalism, his starting point was the work of an Augustinian monk, Martin Luther. This was his "Study on Authority," a contribution to the Institute for Social Research's Studies on Authority and the Family (1936), an exile work published in Paris with material provided by Jewish thinkers dispersed over two continents. For Marcuse the royal road to understanding the catastrophe that had precipitated their flight from Nazi Germany lay in comprehending the genesis of liberalism. He gave an essay he published in 1934 a title that belied his intention in the piece, for the actual claim in "The Struggle against Liberalism in the Totalitarian View of the State" (1934) was that the capitalist basis of liberal ideology meant that a capitalist fascism had deep points of continuity with the liberalism its propaganda misrepresented and caricatured; that in this sense "it is liberalism that 'produces' the total-authoritarian state out of itself, as its own consummation at a more advanced stage of development."3 The "Study on Authority" had the task of showing how from the sixteenth century in Europe, beginning within religious thought, the robust contours of a worldview were crafted that would facilitate the protean needs of an omnivorous capitalism.

As Marcuse knew, the young Marx had seen Luther as the begetter of a new subjectivity in Reformation Germany-a theoretical revolution in "the brain of the monk." In a conception that is clearly echoed in Marcuse's analysis, Marx considers Luther to have engineered the internalization of authority, conceived as freedom, in German Protestantism, summed up in a passage Marcuse quotes in his own text: "Luther, we grant, overcame the bondage of piety by replacing it by the bondage of conviction. He shattered faith in authority because he restored the authority of faith.... He freed man from outer religiosity because he made religiosity the inner man." ${ }^{5}$

3. Herbert Marcuse, "The Struggle Against Liberalism in the Totalitarian View of the State," in Negations, trans. Jeremy J. Shapiro (Harmondsworth: Penguin, 1972), p. 19.

4. Karl Marx, "Contribution to the Critique of Hegel's Philosophy of Law. Introduction," in Karl Marx and Frederick Engels, Collected Works (London: Lawrence and Wishart, 1975), 3:182.

5. Ibid. 
And in the Economic and Philosophic Manuscripts, Marx suggests the future trajectory of this new mentality, drawing on Engels's remark that Adam Smith was the Luther of political economy, with private property being transformed in his conception from a thing external to individuals into their inner core. ${ }^{6}$

Marcuse's encounter with the Economic and Philosophic Manuscripts, shortly after their publication for the first time in 1932, was a pivotal moment for his theoretical development. In a review of the Manuscripts of that same year, one crackling with admiration, the point he was most insistent to make was that we now knew that Marx had provided a philosophical basis for historical materialism, something that Marcuse had been previously searching for in the work of his supervisor at Freiburg, Heidegger. He also drew attention to Marx's debt to Feuerbach, a figure to this day greatly underappreciated, and one who in Marxist circles has seldom had his due. It is, however, as a significant humanist materialist that Marcuse understands Feuerbach's achievements - there is no mention of the powerful analysis of religion that underlay Feuerbach's project and which animated Marx's development of the concepts of alienation and ideology. For this aspect of Feuerbach, the work of Marcuse's older contemporary, Ernst Bloch, is more insightful.

When he came to treat Luther in "A Study on Authority" Marcuse was drawn to the explanatory power of dualism in anatomizing liberal capitalism. Again, an early Marx provenance is likely. Certainly in England at this time in the 1930s the maverick Scottish philosopher John Macmurray had alighted on the concept of dualism following his own study of the German edition of the Economic and Philosophic Manuscripts and other texts of the young Marx, actively encouraged by his friend Karl Polanyi. In Macmurray's case he seems to have been impressed by Marx's analysis in On the Jewish Question where he posits a dual life experienced by people in capitalism - a heavenly one in the realm of free citizenship, and an earthly one in the alienated conditions of civil society - though as a Christian (a highly unorthodox one) he was very conscious of the religious, Feuerbachian roots of this approach in Marx, and in this respect is closer to Bloch than Marcuse. ${ }^{7}$ For Marcuse the notion of a dual existence

6. Karl Marx, "Economic and Philosophic Manuscripts of 1844," trans. Martin Milligan and Dirk J. Struik, in Marx and Engels, Collected Works, 3:290-91.

7. See Vincent Geoghegan, Socialism and Religion: Roads to Common Wealth (London and New York: Routledge, 2011), pp. 22-23. 
provided a handle on the complex dialectic of freedom and unfreedom in liberal capitalism, for "the union of internal autonomy and external heteronomy, the disintegration of freedom in the direction of its opposite is the decisive characteristic of the concept of freedom which has dominated bourgeois theory since the Reformation." 8

Marcuse roots secularism in the religious thought of the Reformation in the opening sentence of his discussion of Luther. Luther's The Freedom of a Christian, he writes, "brought together for the first time the elements which constitute the specifically bourgeois concept of freedom and which became the ideological basis for the specifically bourgeois articulation of authority." "That there was something fundamentally religious about liberal secular society had been argued by Marx in On the Jewish Question. Indeed, he maintained that the liberal secular state was more religious than the old religious state because it "perfected" the dualistic split in individuals between their real and imaginary lives: "they are religious because men treat the political life of the state, an area beyond their real individuality, as if it were their true life." ${ }^{10}$ For Marcuse, Luther's stress on the inner freedom of the individual left the outer person disengaged from and dominated by the external world. More pernicious still was that the inner freedom needed external unfreedom to feel like freedom. He expresses this imperative in Luther's words: "A Christian is free and independent in every respect, a bondservant to none. A Christian is a dutiful servant in every respect, owing a duty to everyone." dualistic doctrine of the two realms, with freedom entirely assigned to one, and unfreedom entirely assigned to the other." ${ }^{12}$ Here is the nature of the real break with medieval Roman Catholicism - a rejection of praxis, a sundering of the link between reason and free activity in the world, a link implied in Aquinas's notion of humans as rational animals. ${ }^{13}$

The reference to Aquinas raises the question of whether Marcuse thought in the "Study" that religious traditions could provide resources of resistance as well as resources of support for capitalism. In a small number of places in the section on the Reformation he does seem to countenance

8. Marcuse, "A Study on Authority," p. 51.

9. Ibid., p. 56.

10. Karl Marx, "On the Jewish Question," trans. Clemens Dutt, in Marx and Engels, Collected Works, 3:159.

11. Marcuse, "A Study on Authority," p. 56.

12. Ibid.

13. Ibid., p. 72 . 
this possibility. Thus in a discussion of scripture he notes that the Decalogue (ten commandments) provided a norm against which "officiating authorities could be 'critically' measured" and noted the incorporation of this idea in later Calvinist attacks on absolutism; ${ }^{14}$ and at a more utopian level, he spoke of the "radical transcendental Christianity of the New Testament." $15 \mathrm{He}$ also noted that Luther's insistence on the freedom of the person "encouraged an anti-authoritarian tendency" that drew on notions of "love, equality, and justice," and "were a recurrent source of anxiety to the rising bourgeoisie owing to their revolutionary application in peasant

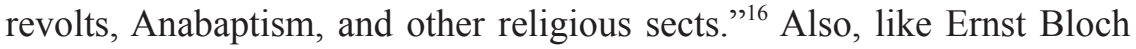
and Karl Mannheim, he was aware of the radical opponent of Luther, Thomas Münzer, and appreciatively quotes Münzer's critique of Luther's defense of authority and property. However this is all very thinly theorized. Furthermore, and obviously not for the last time, he points to the absorptive power of capitalism - here in the person of Calvin. Calvin was responsible for "smoothing-out the contradictions appearing" in Lutheran ideas and for facilitating "the incorporation of these destructive tendencies into the bourgeois order." 17

\title{
Anglo-American Liberalism and the Nature of Tolerance
}

Marcuse's discussion of Luther and Calvin provides the basis for his analysis of the secularization of the Christian bourgeois conception of freedom, first in Kant and then Hegel, the latter in turn providing the link, for Marcuse, to Marx's definitive reading of the rise of liberal thinking. Marcuse in the Study does not discuss another liberal genealogy with deep religious roots-Anglo-American liberalism. The key theoretical and political issue in this tradition - the proper relationship between the public and the private - was massively shaped by the religious wars that erupted in the wake of the Reformation, culminating in the bloody stalemate of the Thirty Years War (1618-48). Toleration, initially a pragmatic necessity grimly conceded, was in the hands of Locke (with his conception of the nature of authentic religious belief) and the deist Jefferson elevated into one of the defining principles of Anglo-American liberalism. Marcuse's

\author{
14. Ibid., p. 69. \\ 15. Ibid., p. 68. \\ 16. Ibid., pp. 65,66 . \\ 17. Ibid., p. 66 .
}


most controversial engagement with this tradition is to be found in his 1965 essay "Repressive Tolerance."

If the context for the "Study" had been the rise of European fascism, the context for "Repressive Tolerance" was Marcuse's conviction that individual autonomy was being systematically undermined in the consumerist societies of western capitalism, most notably the United States. Marcuse had produced his anatomy of such societies the previous year in One Dimensional Man; the opening sentence of the first chapter expressed the seemingly paradoxical nature of his central claim: "A comfortable, smooth, reasonable, democratic unfreedom prevails in advanced industrial civilization, a token of technical progress."18 "Democratic unfreedom" is clearly not the same as fascism, though it still evokes a failure of liberalism - but of a different kind. While the "Study" was premised on a trajectory from liberalism to fascism, One Dimensional Man had to account for a liberal trajectory that in the case of Britain and the United States had not led to this outcome. Marcuse attempts to lessen the gap between fascism and "democratic unfreedom" by calling the advanced western societies "totalitarian," but notes himself that under this term one can distinguish "terroristic political coordination of society" from "nonterroristic economic-technical coordination." "19 This context colors his account of western liberalism. He acknowledges its radical and critical past, albeit constrained by its link to private property, but argues that it has become absorbed and neutralized by the societies its revolutions created: "Freedom of thought, speech, and conscience were... essentially critical ideas.... Once institutionalized, these rights and liberties shared the fate of the society of which they had become an integral part. The achievement cancels the premises." ${ }^{20}$

The neutralization effect of one-dimensional society extends to religion. Religiosity and spirituality flourishes in these conditions: "there is a great deal of 'Worship together this week,' 'Why not try God?,' Zen," ${ }^{\text {,1 }}$ but its function has changed. In effect acknowledging the critical role that religion has played historically, he argues that "such modes of transcendence are no longer contradictory to the status quo and no longer negative." 22

18. Herbert Marcuse, One Dimensional Man (London: Sphere, 1972), p. 16.

19. Ibid., p. 17.

20. Ibid., p. 16 (Marcuse's emphasis).

21. Ibid., p. 25.

22. Ibid. 
They have become part of the furniture of a secular society- "the ceremonial part of practical behaviorism, its harmless negation... quickly digested by the status quo." 23 Again, one recalls Marx's claim that the modern secular state is the most Christian in that it basks in its supposed universality and "relegates religion to a place among the other elements of civil society." 24

Turning to "Repressive Tolerance," 25 we have an essay on the protean nature of the concept of tolerance within liberal discourse-both historically and within contemporary usage; a veritable cubist depiction of distinct facets and aspects. The historical framework is painted in broad brushstrokes and is couched in the language of the Marxist theory of bourgeois revolutions; the political focus is on the experience of AngloAmerican liberalism. In its radical historical phase liberalism is deemed to have practiced "partisan" tolerance involving active intolerance toward the supporters of the old order. Even in England and the United States, he argues, with their "firmly established" liberal societies, while opponents were allowed to speak and assemble freely they were not allowed to "make the transition from word to deed, from speech to action." ${ }^{26}$ This mode of tolerance is contrasted with the "repressive" tolerance of modern liberal democracy, made up of a "passive" tolerance of "entrenched and established attitudes" and an "active" non-partisan stance vis-à-vis Right and Left, reactionary and progressive, which, in conditions of inequality, is thereby actively partisan toward the forces of the status quo. ${ }^{27}$ Repressive tolerance is so perniciously potent for Marcuse because the autonomous individual of classical liberal theory is an endangered species in modern liberal democracy. To develop this argument Marcuse employs the services of John Stuart Mill, who is allowed to present a liberal autocritique. Mill's recoil from the radical democratic hedonism of Bentham, his insertion of a qualitative criterion in assessing pleasure, his fear of the tyranny of the majority, provided a liberal rationalist critique of modern liberal

23. Ibid.

24. Marx, "On the Jewish Question," p. 156.

25. For a useful account of the reception of "Repressive Tolerance," see Rodney Fopp, "Herbert Marcuse's 'Repressive Tolerance' and his Critics," Borderlands: An E-Journal 6:1 (2007).

26. Herbert Marcuse, "Repressive tolerance," in Robert Paul Wolff, Barrington Moore Jr., and Herbert Marcuse, A Critique of Pure Tolerance (London: Jonathan Cape, 1969), pp. 99, 100.

27. Ibid., p. 99. 
democratic society that chimed well with Marcuse's one dimensionality thesis. ${ }^{28} \mathrm{He}$ quotes Mill's assertion that "liberty, as a principle, has no application to any state of things anterior to the time when mankind have become capable of being improved by free and equal discussion," ${ }^{29}$ and he himself asserts that "there is a sense in which truth is the end of liberty, and liberty must be defined and confined by truth."

Marcuse's account of partisan tolerance in practice is complicated because he oscillates between describing a hypothetical context in which this tolerance is central policy, and assessing the terrain of struggle as it exists in actual time. Partisan tolerance for Marcuse, as we have seen, necessarily involved intolerance. Intolerance was remarkably effective. Mill had recognized this when he noted that "the dictum that truth always triumphs over persecution, is one of those pleasant falsehoods which men repeat after one another till they pass into commonplaces, but which all experience refutes"; ${ }^{31}$ and Marcuse concurs with Mill's skeptical judgment about the "inherent power" of truth. ${ }^{32}$ Yet he also recognized with Mill that this effectiveness had frequently been used in the service of tyranny and repression. Where, therefore, given the demands of political realism, were the boundaries to intolerance to be drawn? In terms of the criteria for what should not be tolerated Marcuse suggests an assessment of content and threat, and in terms of the scope of intolerance this could apply to words and actions. When specifying specific possible examples, the net is thrown wide, for this could "include the withdrawal of toleration of speech and assembly from groups and movements which promote aggressive policies, armament, chauvinism, discrimination on the grounds of race and religion, or which oppose the extension of public services, social security, medical care, etc." ${ }^{33}$ As to who is to decide these matters, the hegemony of one-dimensionality means that initially it will be the enterprise of rational minorities, which, given the entrenched political and social power of vested interests, means that extra-legal actions, including violence, could be legitimate.

28. This is not a claim about Mill's actual purposes but simply about his function in Marcuse's argument.

29. Marcuse, "Repressive Tolerance," p. 100.

30. Ibid.

31. John Stuart Mill, "On Liberty," in John Stuart Mill On Liberty and Other Essays, ed. John Gray (Oxford: Oxford UP, 1998), p. 33.

32. Marcuse, "Repressive Tolerance," p. 104.

33. Ibid., p. 114. 
In the presentation of these arguments a curious semantic reversal occurs. Convinced as he was of the dark underbelly of contemporary liberal tolerance, Marcuse uses a range of devices to deflate what he takes to be the pretensions of this discourse: concepts are given negative qualifiers, as in "spurious neutrality," ${ }^{34}$ or are undermined by the addition of negative content ("toleration of sense and nonsense"), ${ }^{35}$ or are linked to their opposite ("freedom ... becomes an instrument for absolving servitude"). ${ }^{36}$ Alongside this however is a strangely positive embrace of a number of anti-liberal concepts. The use of "intolerance" we have already seen. But there is also "censorship" and "precensorship," as when Marcuse says of the prohibiting of reactionary words and deeds, "to be sure, this is censorship, even precensorship, but openly directed against the more or less hidden censorship that permeates the free media," 37 and "discrimination" as in "discriminatory tolerance." 38 There is almost a sense of relish in the breaking of liberalism's taboos.

When quizzed later about "Repressive Tolerance," Marcuse acknowledged that he was "intentionally provocative" in the essay, and the reason he gives for this attitude brings us back to the context of the Study, for he attributes his anger not to any specific U.S. factor but rather to the "new toleration of Nazi and proto-Nazi movements" by the West German state in the 1960s, and that this had looped him back to "what had happened in the Weimar Republic with the toleration of the Nazi movement and other militant movements on the right." 39 And certainly in "Repressive Tolerance" the failure of Weimar liberal democracy to prevent the rise of the Nazis is deemed to point out an important, and to Marcuse a deeply personal and heartfelt, political lesson: "if democratic tolerance had been withdrawn when the future leaders started their campaign, mankind would have had a chance of avoiding Auschwitz and a World War." ${ }^{40}$ From the perspective of this piece of counterfactual speculation, Weimar failed to act as a liberal state and was consequently superseded as a liberal state. The issue of state-capture thus haunts his reflections on toleration-the

\section{Ibid., p. 127.}

35. Ibid., p. 108.

36. Ibid., p. 98.

37. Ibid., p. 125 .

38. Ibid., p. 120.

39. Myriam Miedzian Malinovich, "Herbert Marcuse in 1978: An Interview," Social Research 48, no. 2 (Summer 1981): 381.

40. Marcuse, "Repressive Tolerance," p. 123. 
phenomenon of hostile groups using the freedoms of liberal democracy to capture the state and use it as an instrument to extirpate liberty. Two of the most astute political analysts of early modern Europe, Machiavelli and Hobbes, had theorized the relationship between weak states and political tyranny (where weakness is understood as the lack of an informed resolve to protect the fundamental strengths of the society against opponents) and had anticipated the secular form an effective state theory would require. In Machiavelli's case - in the context of a broken and subjugated Italy-recognition that states are not churches, that overlapping but distinct moralities are necessary in the public and private spheres, informs his account of the flinty duty of the good state. Anything else indicates state weakness, and leads to regime change and the misery of the people. For Hobbes, surveying the carnage of decades of religious wars in Europe, the threat to liberty came from religious fanatics who wished to gain control of states to enforce their dogmas. His strong state, his Leviathan, was thus necessitated by the need to keep religious groups firmly in their place. Likewise for Marcuse the Nazis provided the "most realistic model" 41 of how a liberal state had been captured, and the attendant stark choices that needed to be faced. Certainly the classic liberal words/action distinctionas in Jefferson's “it does me no injury for my neighbor to say there are twenty gods, or no god. It neither picks my pocket nor breaks my leg",42 has in significant ways been collapsed in liberal democratic theory and practice since the days of "Repressive Tolerance" in the form of legislation combating racist and homophobic speech. Furthermore, the terror threat post-9/11 has forced some tough questions to be asked about the extent of civil liberties.

"Repressive Tolerance" has very little to say about the role of religion in a liberal secular society. Two things are of note. First, there is a difference with Mill on the nature of the religious roots of liberalism. In On Liberty Mill, to substantiate his claim about the power of persecution, argues that "the Reformation broke out at least twenty times before Luther, and was put down," and he cites heretics such as Fra Dolcino and Savonarola as examples. ${ }^{43}$ Marcuse clearly sees this as Mill presenting the liberal grand

41. Malinovich, "Herbert Marcuse in 1978," p. 381.

42. Thomas Jefferson, Political Writings, ed. Joyce Appleby and Terence Ball (Cambridge: Cambridge UP, 1999), p. 394.

43. Mill, “On Liberty,” p. 33. 
narrative of the rise of freedom, with the Reformation as a nodal point; for Mill "the criterion of progress in freedom... is the Reformation." for Marcuse, is an undialectical, unhistorical account of the emergence of liberalism that ignores dark contradictions-"Savonarola too would have burned Fra Dolcino" - and lazily equates heresy with truth ("Heresy by itself... is no token of truth"). ${ }^{45}$ Second, there is a brief passing reference to the issue of religious tolerance where Marcuse is attempting to designate those activities that need "indiscriminate tolerance." $\mathrm{He}$ establishes two categories of activity in what appears to be a hierarchy: "indiscriminate tolerance is justified in harmless debates, in conversation, in academic discussion; it is indispensable in the scientific enterprise, in private religion." " If "justified" is a less pressing claim than "indispensable," then religion, so long as it meets the secular criterion of "private," is accorded here a relatively exalted status. If, however, there is no inferred substantive difference underpinning this linguistic usage, this still places religion in a ring-fenced realm of tolerance.

\section{Religion, Science, and the Enlightenment}

The bracketing together of religion and science as needing maximum tolerance raises the question of how Marcuse understood the contemporary relationship between these two practices. He rejects neo-Enlightenment narratives where scientific rationalism is the cutting edge of human progress, and the "decline" of religion is a major measure of the success of its mission. In Eros and Civilization (1955) he takes Freud to task for espousing such a narrative in The Future of an Illusion, where the "illusion" in question is religion. According to Marcuse, Freud thought "that the disappearance of this illusion would greatly accelerate the material and intellectual progress of mankind, and he praised science and scientific reason as the great liberating antagonists of religion." ${ }^{\text {47 }}$ But this is to ignore the fact that in the contemporary world the "function of science and of religion has changed - as has their interrelation." ${ }^{48}$

To understand the direction of this analysis we need to first look at Marcuse's critical appropriation of Freud's exploration of the historical

44. Marcuse, "Repressive Tolerance," p. 105.

45. Ibid.

46. Ibid., p. 102.

47. Herbert Marcuse, Eros and Civilisation (London: Abacus, 1972), p. 64.

48. Ibid. 
psychology of religion, for although he rejects Freud's scientistic Enlightenment optimism he believes that Freud's anthropological and psychological speculations in (above all) Moses and Monotheism provide real insight into the historical dialectic of domination and liberation. He accepts that Freud's positing of an archaic primal horde ruled by a despotic father lacks anthropological evidence, but he argues that it has "symbolic value." In Freud's conjectural "history," rebellious sons overthrow the father and his monopoly on women (sexual pleasure) only fearfully to renounce the liberation they have achieved by patricide and to establish their own order of domination. There is a double guilt here-guilt in killing the father (with its threat of social collapse) and guilt in betraying their goal of overthrowing domination. The historical recurrence of this phenomenon is deemed to be captured in Freud's notion of the "return of the repressed." Taking his cue from Freud's exploration of this "return" in Judaism, Marcuse attempts to do the same for Christianity. Jesus the earthly Messiah undergoes "transubstantiation" and "deification" by his followers; these Christians are, to use Freud's phrase, "badly christened" in that "they accept and obey the liberating gospel only in a highly sublimated form - which leaves the reality unfree as it was before." ${ }^{49}$ This betrayal was resisted by various heretical groups who sought "to rescue the unsublimated content and the unsublimated objective," who were repressed with a bloody and sadistic fury by the Church, where "the executioners and their bands fought the specter of a liberation which they desired but which they were compelled to reject." 50

In Eros and Civilization this characterization of Christianity is slotted into the metanarrative that was to inform One Dimensional Man-"the total mobilization of man and nature." ${ }^{51}$ Science has lost its rational cutting edge, its capacity to negate bad facticity, and has instead become thoroughly positivist, anchoring people in a world of alienation. As such it is "one of the most destructive instruments" in the service of human oppression, "destructive of that freedom from fear which it once promised." The glory days of science battering down the irrational resistances of religion are over. But then religion itself "has equally effectively discarded its explosive elements. ${ }^{, 53}$ Thus, their social functions have become

49. Ibid., p. 63.

50. Ibid., pp. 63-64.

51. Ibid., p. 64.

52. Ibid.

53. Ibid. 
"complementary," dispelling hope and tethering humans to the "reality" of capitalism. However, in a significant qualification of this claim Marcuse in effect reverses the central theme of the neo-Enlightenment narrative by suggesting that insofar as religion has retained its gold-bearing seam of Jesus the earthly Messiah - "the overthrow of the Law (which is domination) by Agape (which is Eros)" $" 54$ - then it is religion and not science that is a vehicle for the repressed truths of the human project: "where religion still preserves the uncompromised aspirations for peace and happiness, its 'illusions' still have a higher truth value than science which works for their elimination." ${ }^{, 55}$ Religion's light would thus oppose science's dark superstition.

\section{Religion, Freedom, and the New Left}

In the late 1960s when the increased tempo of radical political action suggested to Marcuse that events were moving "beyond One-Dimensional Man," ${ }^{, 56}$ his role as a radical public intellectual meant that his theorizing was often expressed in media and spaces where rigor had to be accompanied by accessibility and political savvy. In a lecture delivered in a Connecticut synagogue in 1969, he used Marx's critique of religion to structure his reflections on the Janus-faced aspects of contemporary religion. Marx's analysis he insisted should rightly be the starting point for such reflections, for "even today... no evaluation of the role of religion in changing society can be made without meeting the criticism of religion by Marx." ${ }^{57}$ Essentially Marcuse uses Marx's critical engagement with Feuerbach's analysis of Christianity (though Feuerbach is not mentioned) as expressed in the classic "opium of the people" section of the "Contribution to the Critique of Hegel's Philosophy of Law. Introduction." Marcuse's emphasis is on the double-edged nature of monotheistic religion; it is not

54. Ibid., p. 63.

55. Ibid., p. 65.

56. Douglas Kellner, in volume 2 of The Collected Papers of Herbert Marcuse, shows that what became the optimistic An Essay on Liberation (1969) was originally to be entitled Beyond One-Dimensional Man (Herbert Marcuse, Towards A Critical Theory of Society, vol. 2 of Collected Papers of Herbert Marcuse, ed. Douglas Kellner [London and New York: Routledge, 2001], p. 108). Kellner is owed a serious debt of gratitude for assembling the volumes of the Collected Papers; they significantly add to the range of available Marcuse texts and include Kellner's valuable contextual and introductory material.

57. Herbert Marcuse, "The Role of Religion in a Changing Society," in Philosophy, Psychoanalysis and Emancipation, vol. 5 of Collected Papers of Herbert Marcuse, ed. Douglas Kellner and Clayton Pierce (London and New York: Routledge, 2011), p. 183. 
a simple imposture - "the willful creation of some men or even one man," but is the expression of the experience of oppression, which has then been "organized and exploited by powerful groups." ${ }^{58}$ Thus the phrase "opium of the people" has to be read in conjunction with Marx's conviction that religion has been the heart of a heartless world.

This type of reading and the direction he wished to take it requires some deft exegesis on Marcuse's part, for he undoubtedly knew that the outcome of Marx's sustained critique of religion in 1843-44 was an attitude of malign neglect toward the phenomenon of religion, with Christianity deemed to be a mere vestigial epiphenomenon of more basic processes. Thus in his summing up of Marx's critique he stresses a link between continuing oppression and the utility of religion. The notion of religion as the heart of a heartless world, he says,

emphasizes the need for religion as long as mental and physical oppression prevail and no effective forces striving for change of these conditions are operating. In other words, religion can and should disappear from earth... only by the collective effort to establish justice, equality, and happiness here on earth. And in this way the abolition of religion would presuppose the coming about of a free and just society. ${ }^{59}$

This suggests a continuing theoretical and political space for a radical reworking of the traditions of religion in the process of collective activity. In the case of Marx, however, his few and far between references to religion after 1844 seek to castigate Christianity for its social values, relate it to declining social forces, and document his belief that the proletariat is becoming fundamentally anti-religious - the communist goal of freedom from religion should be operative in the struggle itself. ${ }^{60}$

Marcuse pursues the notion of religion's two functions to explore, elucidate, and contextualize the revolutionary dimension in religion; a utopian role: religion as "articulating and sustaining the vision of a fulfillment of human needs and aspirations for all men"; and a critical role: "a critical, sometimes even radical no to prevailing inequality, injustice, and misery, and in this respect a progressive force." ${ }^{\circ 1}$ The audience is asked to relate to

58. Ibid.

59. Ibid., pp. 183-84 (Marcuse's emphasis).

60. See Vincent Geoghegan, "Religion and Communism: Feuerbach, Marx and Bloch," The European Legacy 9, no. 5 (2004): 590.

61. Marcuse, "The Role of Religion in a Changing Society," p. 184 (Marcuse's emphasis). 
the subversive elements in Judaism by reflecting on a passage from Amos that had been quoted earlier in the gathering. The passage is not identified, but there is much in Amos about social injustice: of those that "sold the righteous for silver, and the poor for a pair of shoes" (2:6) and who "afflict the just... take a bribe... and turn aside the poor in the gate (5:11); and there is the vision of a better earthly time: "Behold, the days come, saith the LORD, that the plowman shall overtake the reaper, and the treader of grapes him that soweth seed; and the mountains shall drop sweet wine, and all the hills shall melt" (9:13). Whatever the precise passage Marcuse describes, it as "one of the best instances for this very concrete, critical, radical, even revolutionary element in religion." ${ }^{.2}$ And while reiterating his long held view that the radical element had become persecuted heresy in the established church, he added "that the canonization of the prophets is one of the rare exceptions in this development." $" 63$

He deploys the concept of "secularization" in an intriguing manner, referring to "a new secularization of religion, not however in the traditional sense" ${ }^{\prime 64}$ that would appear to be a call to move away from the old secular privatization of religion toward a politicization of religion: "The progressive critical elements of religion... must be translated into reality ... and not merely as pious profession of faith on holidays, not merely as a ritual or custom or tradition. In other words ... religion must become, if it makes any effort to take its own truth seriously...the expression of a political attitude and show political concern." ${ }^{, 5}$ This is the only way an affirmative answer can be given to the question - a reformulation of Adorno's famous remark about the possibility of poetry post-Holocaustthat he poses to his audience: "Is religion still possible after Auschwitz?" And he invests great hope in the rebellious potential of youth. He talks of a "radical transformation of the Oedipus complex," where it is the fathers who are guilty, not the sons, which "weakens the sense of guilt which is so essential to religion" (in its negative function). ${ }^{67}$ As with authentic religion in the past, there is a strong moral core in the protest of youth"an anti-puritanism, a libertarian morality, but a morality nevertheless." 68
62. Ibid.
63. Ibid.
64. Ibid., p. 186.
65. Ibid.
66. Ibid., p. 187.
67. Ibid., p. 186.
68. Ibid., p. 187. 
In another lecture he gave in this period, he drew attention to the political contribution made by radical clerics. While Marxist theory was "irreconcilable" with the "dogma" and institutional forms of Christianity, it found an "ally in those tendencies, groups, and individuals committed to the part of Christian teaching that stands uncompromisingly against inhuman, exploitative power," religious tendencies to be found in priests and ministers who have fought oppression and (an interesting formulation) "fascism in all its forms." 69

By the early 1970s the pessimistic tone that had been so prevalent in One Dimensional Man was apparent once more. When asked in a 1973 interview if the Paris events of 1968 had shown One Dimensional Man to have been over-pessimistic, he replied: "It seems to me that unfortunately what I said in my book has been corroborated. Unfortunately!"70 The dark clouds appear in the titles of his work in this period, as in "The Movement in a New Era of Repression" and "The Left under the Counterrevolution," which signal not a simple return to the terrain of One Dimensional Man but rather convey a sense of a new and deeply threatening stage of struggle. ${ }^{71}$ More specifically they contain his last significant reflections on the nature of liberal democracy and its purported modern tendency toward fascism. His focus is primarily the United States, which he declares "is not a fascist regime by any means," but, he adds, the question must be asked as to "whether the present phase of the (preventive) counterrevolution (its democratic-constitutional phase) does not prepare the soil for a subsequent fascist phase." ${ }^{, 72}$ The sentiments are more candid (and angrier) in a fascinating unpublished manuscript of this time with its ambiguous descriptive/prescriptive title "The Historical Fate of Bourgeois Democracy." 73

69. Herbert Marcuse, "Marxism and the New Humanity: An Unfinished Revolution," in Marxism and Radical Religion: Essays toward a Revolutionary Humanism, ed. J. C. Raines and T. Dean (Philadelphia: Temple UP, 1970), p. 10.

70. Herbert Marcuse, "Interview with Marcel Rioux," Forces 22 (1973): 270.

71. Herbert Marcuse, "The Movement in a New Era of Repression: An Assessment," Berkeley Journal of Sociology 16 (1971-72): 1-14; Herbert Marcuse, "The Left under the Counterrevolution," in Counterrevolution and Revolt (London: Allen Lanes, 1972), pp. $1-57$.

72. Marcuse, "The Left under the Counterrevolution," p. 24.

73. Herbert Marcuse, "The Historical Fate of Bourgeois Democracy," in Towards a Critical Theory of Society, pp. 165-86. Kellner provides a valuable contextual note on p. 164. 
Richard Nixon's presidential re-election in 1972 is invested with, from today's perspective, a huge political, symbolic, and indeed historic significance; it "demonstrated" how historically bourgeois democracy had been transformed from a "liberal-progressive" into a "reactionary-conservative society" and indicated that there were only two possible political alternatives, "neo-fascism on a global scale, or transition to socialism," with the former "the most likely one." 74 The possibility of a huge excluded middle is not seriously entertained. In sociopolitical terms Marcuse maintains that modern liberal democracies have expanded their historical hegemonies, enabling them safely to abandon that which once made them revolutionary; it thus gives "itself an enlarged popular base which supports the liquidation of the remnants of the liberal period." ${ }^{75}$ To give this analysis legs he posits a sadomasochistic instinctual identification of this enlarged social base with the political leader. His recommended sources for the details of this process all have roots in the attempts to understand fascist authoritarianism of the Weimar Germany generation: Fromm's contribution to the Studies on Authority and the Family and his Escape from Freedom, Reich's work on the mass psychology of fascism, and Adorno et al.'s The Authoritarian Personality. The net effect of this political/psychological process is that liberal democracy engineers its own destruction:

Rousseau is stood on his head; the General Will is incorporated in the government, rather the executive branch of the government....[T]he underlying population at large becomes the subject-object of politics, of democracy: the people, "free" in the sense and within the limits of capitalism, and in this freedom, reproducing its servitude. ${ }^{76}$

Marcuse does acknowledge that liberal democracy provides more opportunities for political struggle than would be available in a neo-fascist regime, but it is a grudging acknowledgement. The New Left is "faced with the task of defending this democracy," but it is the defense of a "lesser evil: lesser than suicide and suppression." this is to distinguish between capitalism's political and economic forms, where, due to different social temporalities in contemporary capitalism,

74. Ibid., p. 165.

75. Ibid., p. 167.

76. Ibid. (Marcuse's emphasis).

77. Ibid., p. 177. 
"the bourgeois-democratic form 'lags behind' the monopoly and state capitalist structure, and thus preserves liberal institutions germane to a previous historical stage." democracy for reducing its popular base." ${ }^{.79}$ Religion enters this analysis only in its negative ideological form. Christianity is indicted as a death cult that has copper-fastened oppression over the centuries and which has played a vital role in perpetuating the deceptions of liberal democracy: "Ever since the crucified God (Nietzsche has recognized the horror of this symbol), the worship of death... had held sway over civilization.... This ideology has been institutionalized in churches and schools ... it permeates bourgeois democracy, it helps, again, and again, to prevent and 'contain' revolution." 80

\section{Conclusion}

Marcuse sought to express what he took to be the paradoxical nature of liberal democratic capitalism; a conception first developed in the early Marx. This was the view that the most intrusive social formation in human history presented itself as the least-a coup de théatre that required the energy of the entire planet, and when the illusion was in danger the full brutality behind the performance was unleashed in all its naked horror. This meant an ideological struggle over the use and misuse of the term freedom, where the opponents held the high ground, and a critique of one conception of freedom could be construed as an attack on the concept itself. The analytical task, itself political, was to reveal the historical nature of this phenomenon, whose ideological roots Marcuse identified in the Protestant reformulation of the concept of freedom. In the 1969 synagogue lecture discussed earlier, Marcuse returned to the theme of his 1930s "Study":

religion... introjects, internalizes repression....The most obvious instance of this... we find in Luther's... concept of Christian liberty, according to which man is perfectly free even in chains, even in prison, because his freedom is an inner freedom, and an inner freedom only - freedom of conscience, freedom of thought — which is perfectly compatible with the most oppressive existential condition. ${ }^{81}$

78. Ibid., p. 178.

79. Ibid.

80. Ibid., p. 173.

81. Marcuse, "The Role of Religion in a Changing Society," p. 184. 
Religion was the discourse in which this new conception of freedom was framed and broadcast, and yet religious discourse contained other elements that spoke of genuine untrammeled freedom, speaking truth to power.

Convinced as he was of the structurally determined weaknesses of liberal constitutionalism - etched into his soul by the Nazi capture of the Weimar state- he always found it difficult to celebrate (to use Bloch's phrase) the "cultural surplus" 82 of political liberalism. He was prepared to defend liberal democracy against the forces of reaction in the 1970s, but this was couched in the downbeat language of a "lesser evil." There is indeed a plausible counterargument to his analysis of the relationship between liberalism and fascism that casts the former in a much more positive light, namely, that it was the relative weakness of liberalism in Germany and the concomitant strength of socialism and communism that attracted vested interests to fascism; in Britain, by contrast, a strong liberalism, which helped keep the main party of the Left a reformist "Labour" and not a radical "Socialist" party ("Under British conditions, a Socialist Party is the last, not the first, form of the Socialist movement in politics" ${ }^{\text {"83 }}$ ), meant that fascism was rendered an unattractive and unnecessary option; ${ }^{84}$ "socialism" was eventually to reach Germany on the tanks of the successors of another nineteenth-century great power that had a minimal liberal tradition-Russia. Certainly in today's ideological climate, where, nationally and internationally, liberal secularism has come under increasing attack, a strong defense of the heritage of liberalism as part of a post-secularist critique of hyper-secularism is a political necessity, socialists included.

82. The notion that certain cultural forms generate a "surplus" that endures beyond the period of its genesis. This surplus consists of intimations of a fuller existence that are "not-yet." See Vincent Geoghegan, Ernst Bloch (London and New York: Routledge, 1996), pp. 48-49, 54-55.

83. Ramsay MacDonald, who was to become the first British Labour Prime Minister, writing in 1911. Quoted in Bernard Crick, Socialism (Milton Keynes: Open UP, 1987), p. 70. Mind you, MacDonald's subsequent entry into a conservative-dominated "national government," which split the Labour Party, could be seen as bolstering Marcuse's case against liberal-democratic parliamentarianism.

84. See, for example, Robert Wuthnow, Communities of Discourse: Ideology and Social Structure in the Reformation, the Enlightenment, and European Socialism (Cambridge, MA: Harvard UP, 1989), pp. 377-445. 